\title{
Faktor yang Mempengaruhi Pelaksanaan Nursing Center di Puskesmas Kota Bandung
}

\author{
Factors Influencing the Implementation of Nursing Center at Puskesmas in Bandung City
}

\section{Ani Susiani}

Akper Saifuddin Zuhri, Indramayu

e-mail: mysusiani@gmail.com,aksari_zuhri@yahoo.com

\begin{abstract}
Abstrak
Upaya untuk meningkatkan kinerja perawat Perkesmas dalam mengatasi permasalahan kesehatan masyarakat dapat dilakukan melalui pelaksanaan Nursing Center (NC) yang memadukan pengelolaan pendidikan, pelayanan kesehatan, penelitian keperawatan, dan pelayanan informasi kesehatan. Tujuan penelitian ini adalah untuk mengetahui perbedaan faktor sumber daya manusia (SDM), pendanaan, material, dan dukungan antara NC yang tidak aktif dan NC yang aktif di Puskesmas Kota Bandung. Jenis penelitian ini adalah analitik dengan desain case control. Sampel yang digunakan sebanyak 32 responden dan pengumpulan data dilakukan dengan menggunakan kuesioner. Hasil penelitian menunjukkan perbedaan yang bermakna pada faktor sumber daya manusia ( $p$ value 0,000 ), pendanaan ( $p$ value 0,019 ), material ( $p$ value 0,005$)$, dan dukungan ( $p$ value 0,004 ) antara NC yang tidak aktif dan NC yang aktif. Diharapkan melalui penyelenggaraan pelatihan mengenai NC secara berkala dan berkesinambungan serta peningkatan kerjasama dengan Institusi Pendidikan Keperawatan oleh Dinas Kesehatan dapat meningkatkan pelaksanaan dan ketercapaian output NC.
\end{abstract}

Kata Kunci: Nursing Center, Perkesmas, Puskesmas

\begin{abstract}
Efforts to improve the performance of PHC nurses in implementing Public Health Nursing (PHN) can be done through the implementation of Nursing Center (NC). NC integrate education, health care, research, and information center for the public health. The purpose of this study was to determine differences in factors of human resources (HR), finance, materials, and support between NC and NC inactive active in Bandung Health Center. This research is an analytic case-control design. The samples used were 32 respondents and data collection using questionnaires. The results showed significant differences in the human resource factor ( $p$ value 0.000), funding ( $p$ value $=0.019)$, material ( $p$ value $=0.005$ ), and support ( $p$ value 0.004 ) between $N C$ and $N C$ are not active active. It is expected that through training on NC periodicly and continuously also by increasing cooperation
\end{abstract}

with nursing education institution by the Department of Health can improve implementation and achievement of NC.

Keywords: Nursing center, PHN, PHC

\section{Pendahuluan}

Keperawatan Kesehatan Masyarakat (Perkesmas) atau dikenal juga dengan istilah Keperawatan Komunitas merupakan salah satu program pengembangan Puskesmas yang terintegrasi dengan keseluruhan program wajib Puskesmas. Perkesmas memiliki tujuan utama memandirikan masyarakat dalam memenuhi kebutuhan kesehatannya. Tujuan ini sesuai dengan tujuan pembangunan kesehatan Bangsa Indonesia. ${ }^{1}$

Kegiatan pelayanan yang dilakukan Perkesmas dilakukan melalui serangkaian proses keperawatan sebagai kegiatan pemecahan masalah kesehatan yang dihadapi individu, keluarga, kelompok risiko tinggi maupun masyarakat sebagai sasasran pelayanan. Proses tersebut diawali dengan kegiatan pengkajian, perencanaan, implementasi, dan evaluasi keperawatan. Melalui kegiatan Perkesmas, masyarakat diharapkan memiliki pengertian, kebiasaan, dan perilaku hidup sehat sehingga mampu memiliki daya ungkit terhadap upaya pemeliharaan dan pencapaian derajat kesehatan yang setinggi-tingginya. ${ }^{1}$

Proses keperawatan yang dilakukan oleh perawat-perawat komunitas di Alberta dan Florida mampu mengatasi masalah-masalah kesehatan masyarakat di daerah tersebut, khususnya ibu hamil dan keluarga miskin 
sebagai klien, yang dibuktikan dengan terjadinya peningkatan pengetahuan dan keterampilan tentang kesehatan serta mendekatkan klien pada sumber pelayanan kesehatan primer dan rujukan yang diperlukan 2,3. Bila dibandingkan dengan perawat-perawat komunitas di Indonesia, realisasi pelaksanaan Program Perkesmas belum berjalan sesuai dengan tujuan yang diharapkan. Penelitian yang dilakukan di Kabupaten Agam mengungkapkan bahwa pelaksanaan Perkesmas belum memberikan kontribusi yang memadai terhadap cakupan Perkesmas ${ }^{4)}$. Demikian juga penelitian yang dilakukan di Sleman mengungkapkan bahwa perawat Puskesmas di Kabupaten Sleman yang melakukan Program Perkesmas sesuai dengan uraian tugas hanya berjumlah $33,01 \%{ }^{5}$

Perawat Perkesmas lebih mengutamakan upaya kuratif dan rehabilitatif serta cenderung mengabaikan upaya promotif dan preventif. Survei yang dilakukan oleh Subdit Keperawatan Dasar Depkes pada tahun 2005 menunjukkan bahwa terdapat $78 \%$ perawat melakukan diagnosis penyakit, $79 \%$ perawat membuat/menulis resep obat, dan $87 \%$ perawat memberikan tindakan pengobatan ${ }^{6}$. Selain hal tersebut, sejumlah program kesehatan di Indonesia dan pendanaannya masih berfokus pada upaya mengobati orang yang sakit saja, bukan mencari akar permasalahan yang menjadi penyebab mereka jatuh sakit kemudian menyelesaikannya. ${ }^{7,8}$

Kenyataan tersebut mengakibatkan kurangnya pelatihan teknis mengenai peningkatan kinerja dan kompetensi Perawat Perkesmas untuk menjalankan peran dan fungsinya dalam memberikan pelayanan kesehatan di masyarakat. Survei yang dilakukan oleh Subdit Keperawatan Dasar Depkes pada tahun 2005 menunjukkan bahwa hanya $25,9 \%$ perawat yang mengikuti pelatihan mengenai peran dan fungsinya. ${ }^{6}$ Laporan mengenai Kebijakan Perkesmas di Jawa Barat pun mengungkapkan bahwa selama tahun 2012, kegiatan monitoring dan evaluasi Program Perkesmas tidak dilakukan secara mandiri namun mengikuti kegiatan monitoring dan evaluasi program Puskesmas yang lainnya diakibatkan oleh minimnya pendanaan yang dialokasikan.

Kurangnya pelatihan teknis dan minimnya penyediaan dana untuk kegiatan monitoring serta evaluasi tersebut mengakibatkan berkurangnya kemampuan dan motivasi perawat, sehingga pelaksanaan Program Perkesmas dalam menunjang kinerja Puskesmas belum berjalan sesuai dengan tujuan yang diharapkan. ${ }^{10} \mathrm{Di}$ pihak lain, tingkat pendidikan dan keterampilan yang dimiliki oleh perawat sebagai sumber daya manusia terbesar di Puskesmas $(28,3 \%)$, akan sangat memengaruhi kinerja organisasi Puskesmas dalam mencapai tujuannya. 11, 12, 13, 14

Permasalahan-permasalahan tersebut memerlukan upaya penanganan sehingga perawat Perkesmas dapat melaksanakan peran dalam menggerakan Puskesmas untuk mencapai tujuan pendiriannya. Nursing Center (NC) atau Sentra Keperawatan, hadir sebagai upaya untuk meningkatkan kinerja perawat Perkesmas dengan memadukan pengelolaan pendidikan, pelayanan kesehatan, penelitian keperawatan, dan pelayanan informasi kesehatan. ${ }^{15,16}$

Laporan Kegiatan Perkesmas (PHN) Dinas Kesehatan Kota Bandung Tahun 2012 menunjukkan bahwa Puskesmas-puskesmas yang aktif menjalankan $\mathrm{NC}$ mengalami kenaikan persentase jumlah keluarga mandiri (KM) IV pada triwulan IV bila dibandingkan dengan jumlah persentase KM IV pada triwulan I. sebagai contoh pada UPT Puskesmas Pasir Kaliki mengalami kenaikan sebesar 13,946\% dan UPT Puskesmas Kopo mengalami kenaikan sebesar 38,049\%. ${ }^{9}$ Evaluasi program NC dapat dilihat dengan menggunakan pendekatan sistem. ${ }^{17}$, yang terdiri dari indikator input (sumber daya manusia, pendanaan, material, dukungan), proses (kegiatan pendidikan, kegiatan 
pelayanan, kegiatan penelitian, kegiatan sistem informasi kesehatan), dan output (terselenggaranya pendidikan, pelayanan, penelitian, dan pelayanan informasi kesehatan). ${ }^{15,16}$ Ketercapaian indikator output sebagai hasil dari indikator input dan proses pada Puskesmas yang melaksanakan NC sampai saat ini belum diketahui, termasuk faktor-faktor yang memengaruhi pelaksanaannya. Berdasarkan hal-hal tersebut, penelitian ini berupaya mendapatkan informasi lebih dalam mengenai faktor-faktor yang memengaruhi pelaksanaan NC di Puskesmas Kota Bandung.

\section{Metode Penelitian}

Metode penelitian ini ini adalah analitik kuantitatif dengan desain case control. Penelitian ini dimulai dengan mengidentifikasi unit penelitian: Puskesmas yang tidak aktif menjalankan NC sebagai kelompok kasus dan Puskesmas yang aktif menjalankan NC sebagai kelompok kontrol berdasarkan rekomendasi Dinas Kesehatan Kota Bandung. Populasi penelitian ini adalah seluruh sumber daya manusia, terdiri dari tenaga keperawatan, baik perawat maupun bidan, dokter, dan tenaga pendidik (dosen Mata Ajar Keperawatan Komunitas, untuk selanjutnya disebut dosen) yang berperan dalam pelaksanaan NC di Puskesmas-puskesmas Kota Bandung. Teknik sampling yang digunakan adalah purposive sampling, dan terpilih 32 responden terdiri dari perawat, bidan, dokter, dan dosen yang masing-masing berjumlah empat responden dengan kriteria terlibat dalam pelaksanaan NC, memiliki masa kerja di Puskesmas penyelenggara NC minimal selama setahun dan tiga tahun untuk dosen, dan bersedia menjadi responden penelitian. ${ }^{18}$

Penelitian ini dilaksanakan pada tanggal 221 September 2013 di Puskesmas-puskesmas penyelenggara $\mathrm{NC}$ yang berada di wilayah kerja Dinas Kesehatan Kota Bandung sejumlah 8 UPT Puskesmas, meliputi: UPT Puskesmas Ciumbuleuit, Taman Sari,
Arcamanik, dan Cikutra Lama sebagai kelompok kasus, serta UPT Puskesmas Pasir Kaliki, Kopo, Griya Antapani, Ujungberung Indah sebagai kelompok kontrol.

Data-data penelitian dikumpulkan melalui kuesioner dan wawancara. Kuesioner telah diujicobakan di Puskesmas Banjaran yang berada di wilayah kerja Dinas Kesehatan Kabupaten Bandung pada tanggal 19-27 Agustus 2013. Uji validitas yang dilakukan adalah content validity (validitas isi) yaitu dengan meminta pendapat pakar/ahli dalam bidang NC yaitu Bapak Mamat Lukman, SKM., S.Kp., M.Si., selaku salah satu anggota Tim Kerja pengembangan Program Keperawatan Komunitas Propinsi Jawa Barat, berdasarkan Surat Keputusan Kepala Dinas Kesehatan Propinsi Jawa Barat Nomer: 441.8/SK.11405-Yankes/2002, yang juga menyusun Pedoman Teknis Sentra Keperawatan. Uji reliabiltas menggunakan rumus Cronbach Alpha dengan Cut off minimal $0,60 .{ }^{19}$ Hasil uji reliabilitas menunjukkan semua variabel dalam kuesioner adalah reliabel, kecuali variabel pendanaan (X2). Namun, penulis tidak mengahapus atau memperbaiki hasil uji reliabilitas untuk variabel pendanaan (X2), karena uji validitas yang digunakan adalah validitas isi. ${ }^{20}$

Analisi data dilakukan secara bertahap mulai dari analisis univariat (distribusi frekuensi), bivariat (Mann Withney Test) dan multivariat (multiple logistic regretion) dengan menggunakan program komputer. ${ }^{21,22,23}$

\section{Hasil}

Hasil penelitian menunjukkan hal-hal sebagai berikut:

Analisis Univariat

1. Deskripsi Karakteristik Responden

Hasil pengumpulan data umum responden pada penelitian ini menggambarkan karakteristrik yang meliputi jenis kelamin, usia, pendidikan, pekerjaan dan masa kerja. Karakteristik responden dilihat berdasarkan jenis 
kelamin, usia, pendidikan, dan masa kerja, seperti tertera pada tabel 1:

Tabel 1. Distribusi Frekuensi Responden berdasarkan Jenis Kelamin, Usia, Pendidikan, dan Masa Kerja

\begin{tabular}{lccc}
\hline \multicolumn{2}{c}{ Karakteristik } & $\mathrm{f}$ & $\%$ \\
\hline Jenis & Laki-laki & 3 & 9,4 \\
Kelamin & Perempuan & $\mathbf{2 9}$ & $\mathbf{9 0 , 6}$ \\
& Total & 32 & 100,0 \\
Usia & $25-30$ & 4 & 12,5 \\
(tahun) & $\mathbf{3 1 - 3 5}$ & $\mathbf{1 1}$ & $\mathbf{3 4 , 4}$ \\
& $36-40$ & 6 & 18,8 \\
& $41-45$ & 2 & 6,3 \\
& $46-50$ & 9 & 28,1 \\
& Total & 32 & 100,0 \\
Pendidikan & D3 & $\mathbf{1 5}$ & $\mathbf{4 6 , 9}$ \\
& S1 & 8 & 25,0 \\
\hline
\end{tabular}

\begin{tabular}{cccc} 
& S2 & 9 & 28,1 \\
Masa Kerja & Total & 32 & 100,0 \\
(tahun) & 1 & 0 & 0,0 \\
& 2 & 1 & 3,1 \\
& 3 & 8 & 25,0 \\
& 4 & 3 & 9,4 \\
& 5 & 8 & 25,0 \\
& $>\mathbf{6}$ & $\mathbf{1 2}$ & $\mathbf{3 7 , 5}$ \\
& Total & $\mathbf{3 2}$ & $\mathbf{1 0 0 , 0}$ \\
\hline
\end{tabular}

Tabel 1 menggambarkan bahwa dari sampel yang digunakan sebagai responden hampir seluruhnya $(90,6 \%)$ berjenis kelamin perempuan, hampir sebagian $(34,4 \%)$ berusia 31-35 tahun, sebagian besar (46,9\%) berpendidikan D3, dan dengan masa kerja lebih dari 6 tahun sebanyak 12 responden $(37,5 \%)$.

\section{Input Nursing Center}

Tabel 2 Distribusi Frekuensi Ketersediaan Input dan Pelaksanaan Nursing Center

\begin{tabular}{|c|c|c|c|c|c|c|}
\hline \multirow{2}{*}{ Sumber Daya Manusia } & \multicolumn{2}{|c|}{ NC Tidak Aktif } & \multicolumn{2}{|c|}{ NC Aktif } & \multicolumn{2}{|c|}{ Total } \\
\hline & $\mathrm{F}$ & $\%$ & $\mathrm{~F}$ & $\%$ & $\mathrm{~F}$ & $\%$ \\
\hline Kurang & 12 & 75,0 & 5 & 31,2 & 17 & 53,1 \\
\hline Baik & 4 & 25,0 & 11 & 68,8 & 15 & 46,9 \\
\hline Total & 16 & 100,0 & 16 & 100,0 & 32 & 100,0 \\
\hline \multicolumn{7}{|l|}{ Pendanaan } \\
\hline Kurang & 15 & 93,8 & 14 & 87,5 & 29 & 90,6 \\
\hline Baik & 1 & 6,2 & 2 & 12,5 & 3 & 9,4 \\
\hline Total & 16 & 100,0 & 16 & 100,0 & 32 & 100,0 \\
\hline \multicolumn{7}{|l|}{ Material } \\
\hline Kurang & 13 & 81,2 & 4 & 25,0 & 17 & 53,1 \\
\hline Baik & 3 & 18,8 & 12 & 75,0 & 15 & 46,9 \\
\hline Total & 16 & 100,0 & 16 & 100,0 & 32 & 100,0 \\
\hline \multicolumn{7}{|l|}{ Dukungan } \\
\hline Kurang & 11 & 68,8 & 6 & 37,5 & 17 & 53,1 \\
\hline Baik & 5 & 31,2 & 10 & 62,5 & 15 & 46,9 \\
\hline Total & 16 & 100,0 & 16 & 100,0 & 32 & 100,000 \\
\hline \multicolumn{7}{|l|}{ Pelaksanaan } \\
\hline Kurang & 11 & 68,8 & 3 & 18,8 & 14 & 43,8 \\
\hline Baik & 5 & 31,2 & 13 & 81,2 & 18 & 56,2 \\
\hline Total & 16 & 100,0 & 16 & 100,0 & 32 & 100,000 \\
\hline
\end{tabular}


3. Perbedaan Faktor Input pada NC yang Tidak Aktif dan NC yang aktif terhadap Pelaksanaan NC

Tabel 3 Perbedaan Faktor Sumber Daya Manusia, Pendanaan, Material, dan Dukungan pada NC yang Tidak Aktif dan NC yang Aktif terhadap Pelaksanaan NC

\begin{tabular}{|c|c|c|c|}
\hline Variabel & $\mathrm{NC}$ & Mean & $p$ value \\
\hline \multirow{3}{*}{$\begin{array}{c}\text { Sumber daya } \\
\text { manusia }\end{array}$} & Tidak & 0,187 & \multirow{3}{*}{0,000} \\
\hline & Aktif & 0,101 & \\
\hline & Aktif & 0,625 & \\
\hline \multirow{3}{*}{ Pendanaan } & Tidak & 0,062 & \multirow{3}{*}{0,019} \\
\hline & Aktif & & \\
\hline & Aktif & 0,219 & \\
\hline \multirow{2}{*}{ Material } & Tidak & 0,194 & \multirow{2}{*}{0,005} \\
\hline & $\Delta k_{t i f}$ & 0525 & \\
\hline \multirow{3}{*}{ Dukungan } & Tidak & & \multirow{3}{*}{0,004} \\
\hline & Aktif & 0,291 & \\
\hline & Aktif & 0,719 & \\
\hline
\end{tabular}

Berdasarkan tabel 3 didapatkan bahwa pada pelaksanaan NC yang tidak aktif dan yang aktif terdapat perbedaan yang bermakna pada faktor sumber daya manusia ( $p$ value 0,000 ), faktor pendanaan ( $p$ value 0,019), faktor material (menunjukkan $p$ value 0,005), dan faktor dukungan ( $p$ value 0,004$)$.

\section{Variabel yang Paling Berpengaruh terhadap Pelaksanaan NC}

Analisis multivariat variabel-variabel independen terhadap variabel dependen penelitian dilakukan dengan cara melakukan seleksi terhadap variabel-variabel independen yang akan diikutsertakan kedalam analisis regresi logistik multivariat, dengan kriteria variabel tersebut memiliki $p$ value $<0,25$ dalam regresi logistik bivariatnya. Hasil regresi logistik bivariat antara setiap variabel independen dengan variabel dependen dapat dilihat pada tabel 4:
Tabel 4. Hasil Regresi Logistik Bivariat

\begin{tabular}{cc}
\hline Variabel & $p$-value \\
\hline Sumber daya manusia (X1) & 0,030 \\
Pendanaan (X2) & 0,999 \\
Material (X3) & 0,150 \\
Dukungan (X4) & 0,150 \\
\hline
\end{tabular}

Tabel 4, menunjukkan bahwa semua variabel independen memiliki $p$ value $<0,25$ sehingga memenuhi multivariat, kecuali variabel pendanaan karena memiliki $p$ value 0,999. Hasil regresi logistik multivariat antara setiap variabel independen dengan variabel dependen dapat dilihat pada tabel 5:

Tabel 5 Hasil Regresi Logistik Multivariat

\begin{tabular}{ccc}
\hline Variabel & $p$-value & OR \\
\hline Sumber daya manusia & 0,054 & 13,449 \\
(X1) & 0,055 & 7,247 \\
Material (X3) & 0,832 & 1,305 \\
Dukungan (X4) & \\
\hline
\end{tabular}

Tabel 5 menunjukkan bahwa dengan taraf kesalahan alpha 0,05 tidak ada satupun variabel independen yang berpengaruh terhadap variabel dependen (Y), sehingga regresi logistik multivariat tersebut dianalisis dengan menggunakan metode Backward Likelihood Ratio (LR). Hasil analisis metode ini dapat dilihat pada tabel 6 :

Tabel 6. Hasil Regresi Logistik Multivariat Likelihood Ratio (LR)

\begin{tabular}{cccc}
\hline Langkah & Variabel & $\begin{array}{c}p- \\
\text { value }\end{array}$ & OR \\
\hline \multirow{2}{*}{1} & Sumber daya & 0,054 & 13,449 \\
& manusia (X1) & & \\
& Material (X3) & 0,055 & 7,247 \\
& Dukungan (X4) & 0,832 & 1,305 \\
\hline \multirow{2}{*}{2} & Sumber daya & $\mathbf{0 , 0 0 7}$ & $\mathbf{1 6 , 2 4 8}$ \\
& manusia (X1) & $\mathbf{0 , 0 4 1}$ & $\mathbf{7 , 7 2 2}$ \\
\hline
\end{tabular}


Langkah ke-2 pada tabel 6 menunjukkan bahwa dengan metode LR, dari ketiga variabel independen yang telah lolos seleksi regresi logistik multivariat, ternyata hanya dua variabel yang signifikan, yaitu sumber daya manusia (X1) dan material (X3) dengan masing-masing $p$ value 0,007 dan 0,041 serta nilai OR (Odds Ratio) 16,248 dan 7,722. Hal tersebut menunjukkan bahwa sumber daya manusia yang baik akan memberikan efek sebesar 16,248 kali lebih besar dibandingkan dengan sumber daya manusia yang kurang baik terhadap keberhasilan (kategori baik) pada pelaksanaan $\mathrm{NC}$, dan ketersediaan material yang baik akan memberikan efek 7,722 kali lebih besar dibandingkan material kurang baik terhadap keberhasilan (kategori baik) pada pelaksanaan NC.

\section{Pembahasan}

\section{Distribusi Responden}

Penelitian ini tidak mengukur pengaruh karakteristik responden terhadap pelaksanaan NC, karena hal tersebut, peneliti tidak akan menguraikan karakteristik sumber daya manusia yang menjadi responden penelitian.

\section{Input Nursing Center}

Perbedaan Faktor Sumber Daya Manusia pada NC yang Tidak Aktif dan NC yang Aktif Sumber daya manusia merupakan komponen input yang berperan dalam penyelenggaraan pelayanan kesehatan. ${ }^{17}$ Lebih dari setengah Puskesmas di Kota Bandung yang menyelenggarakan NC termasuk dalam kriteria kurang untuk faktor sumber daya manusia dalam pelaksanaan kegiatan $\mathrm{NC}$, yaitu sebesar 53,125\%. Penelitian yang dilakukan oleh Septino (2007) yang mengemukakan bahwa, sumber daya manusia khususnya koordinator Perkesmas, berperan penting dalam keberhasilan pelaksanaan program Perkesmas melalui pemberian pengarahan kepada perawat pelaksana tentang bagaimana seharusnya program tersebut dilaksanakan. ${ }^{24}$

Kegiatan NC sebagai bagian dari kegiatan Puskesmas dilakukan oleh perawat-perawat fungsional yang bekerja sama dengan tenaga kesehatan lain dalam memberikan pelayanan kesehatan ${ }^{1)}$. Demikian pula halnya dengan NC yang dilakukan oleh Puskesmas-puskesmas di Bandung. Sumber daya manusia yang terlibat dalam pelaksanaan NC bukan hanya perawat, namun melibatkan tenaga bidan, dokter, dan dosen dari institusi pendidikan.

Keterlibatan tenaga kesehatan lain, termasuk dosen, dokter, dan bidan pada Puskesmas dengan NC yang tidak aktif, hanya ditemukan pada satu dari empat Puskesmas. Padahal, penelitian sebelumnya menunjukkan kerjasama antar tenaga kesehatan dapat meningkatkan kualitas pelayanan yang diberikan kepada masyarakat. ${ }^{2,25}$

\section{Perbedaan Faktor Pendanaan pada NC yang Tidak Aktif dan NC yang Aktif}

Hasil penelitian menunjukkan bahwa ada perbedaan faktor pendanaan yang bermakna pada pelaksanaan $\mathrm{NC}$ yang tidak aktif dan $\mathrm{NC}$ yang aktif berdasarkan tabel 4 dengan $p$ value 0,019 . Hasil penelitian pun menunjukkan bahwa NC yang aktif memiliki ketersediaan pendanaan lebih besar (mean 0,219) bila dibandingkan dengan ketersediaan pendanaan pada NC yang tidak aktif (mean 0,062).

Pendanaan termasuk dalam input yang menunjang semua kegiatan yang dilakukan oleh petugas kesehatan dalam memberikan pelayanan kepada masyarakat dan keberhasilan pengelolaan suatu kegiatan. 17, 26 Penelitian mengenai hubungan pendanaan dengan pelaksanaan NC belum pernah dilakukan. Namun penelitian- penelitian sebelumnya menunjukkan bahwa faktor pendanaan mempengaruhi keaktifan pelaksanaan program-program kesehatan, seperti pelaksanaan Posyandu ${ }^{27}$, sistem informasi kesehatan ${ }^{28}$, maupun pelaksanaan Perkesmas. ${ }^{10}$ 


\section{Perbedaan Faktor Material pada NC yang Tidak Aktif dan NC yang Aktif}

Hasil penelitian menunjukkan bahwa ada perbedaan faktor material yang bermakna pada pelaksanaan NC yang tidak aktif dan NC yang aktif dengan $\quad p$ value 0,005 . Ketersediaan material pada NC yang aktif lebih besar mean $(0,525)$ bila dibandingkan dengan $\mathrm{NC}$ yang tidak aktif (mean 0,194).

Hasil penelitian ini sesuai dengan hasil penelitian sebelumnya yang menjelasakan bahwa terdapat hubungan yang signifikan antara ketersediaan sarana dan prasarana dengan hasil kegiatan imunisasi dasar bayi oleh petugas imunisasi Puskesmas di Kabupaten Blora. ${ }^{29}$ Sebaliknya, sarana dan prasarana yang tidak sesuai dengan standar pelaksanaan akan mengakibatkan kegiatan pelayanan yang diberikan menjadi tidak maksimal. ${ }^{30}$

Hasil penelitian ini dan penelitianpenelitian sebelumnya sesuai dengan pendapat ahli. Faktor material sebagai bagian dari input NC diperlukan untuk menunjang pelaksanaan pelayanan kesehatan. 16,17 Pedoman penyelenggaraan upaya keperawatan kesehatan masyarakat di Puskesmas menyebutkan bahwa indikator masukan yang menunjang keberhasilan pelaksanaan Perkesmas diantaranya adalah tersedianya PHN Kit, sarana transportasi, standar pelaksanaan kegiatan, dukungan administrasi (buku register, family folder, formulir askep, formulir laporan, dll), serta tersedianya ruangan khusus untuk asuhan keperawatan di Puskesmas. ${ }^{1}$

\section{Perbedaan Faktor Dukungan pada NC yang Tidak Aktif dan NC yang Aktif}

Hasil penelitan menunjukkan bahwa ada perbedaan faktor dukungan yang bermakna pada pelaksanaan NC yang tidak aktif dan NC yang aktif berdasarkan tabel 4 dengan $p$ value 0,004 . NC yang aktif memiliki dukungan lebih besar (mean 0,719 ) bila dibandingkan dengan dukungan pada NC yang tidak aktif (mean 0,297).

Hasil penelitian ini mendukung penelitianpenelitian sebelumnya mengenai pentingnya dukungan bagi terselenggaranya suatu kegiatan. Sebagai contoh, kurangnya dukungan dari Kepala Puskesmas terhadap koordinator Perkesmas di wilayah kerja Dinas Kesehatan Kota Semarang mengakibatkan tugas pokok koordinator Perkesmas belum terlaksana dengan baik. ${ }^{31}$ Penelitian lainnya menunjukkan bahwa kurangnya dukungan pemerintah daerah dalam pelaksanaan program Perkesmas menjadi salah satu penyebab masih rendahnya cakupan program Perkesmas di Puskesmas Daerah Sumatera Barat. ${ }^{24}$

Dukungan pada pelaksanaan NC, sebagaimana yang telah dijelaskan di atas, memiliki pengaruh yang signifikan. Dukungan tersebut tidak hanya berasal dari Kepala Puskesmas, namun juga berasal dari Dinas Kesehatan melalui Bagian Bina Pelayanan Kesehatan, Institusi Pendidikan Keperawatan dan pemerintah daerah.

\section{Variabel Paling Dominan yang Memengaruhi Pelaksanaan Nursing Center}

Faktor yang memengaruhi pelaksanaan NC paling dominan adalah sumber daya manusia. Ketersediaan faktor sumber daya manusia akan memberikan pengaruh 16,248 kali lebih besar terhadap pelaksanaan NC bila dibandingkan dengan sumber daya manusia yang kurang. Faktor lain yang memengaruhi pelaksanaan NC adalah material. Ketersediaan material yang baik akan memberikan pengaruh sebesar 7,722 kali lebih besar terhadap pelaksanaan NC dibandingkan material yang kurang (tabel 6). Seperti penjelasan di atas, hasil penelitian ini sesuai dengan indikator masukan (input) pada pelaksanaan Perkesmas kecuali faktor pendanaan.

Faktor pendanaan dan faktor dukungan secara statistik tidak menunjukkan adanya pengaruh yang signifikan terhadap pelaksanaan 
$\mathrm{NC}$, namun bukan berarti bahwa kedua faktor tidak diperlukan dalam pelaksanaan NC. Wawancara yang dilakukan dengan Kepala Bidang Bina Pelayanan Kesehatan Dinas Kesehatan Kota Bandung mengemukakan bahwa NC yang dilaksanakan di Puskesmaspuskesmas Kota Bandung sesungguhnya adalah penerapan program Perkesmas, sehingga dana yang digunakan dalam pelaksanaan $\mathrm{NC}$ adalah dana yang sama yang digunakan untuk kegiatan Perkesmas. Hal ini sesuai dengan pengakuan para koordinator NC pada Puskesmas yang aktif melaksanakannya, bahwa pendanaan yang digunakan untuk kegiatan pelayanan NC berasal dari dana operasional Perkesmas.

Faktor dukungan atas pelaksanaan NC secara statistik juga tidak menunjukkan adanya pengaruh yang signifikan terhadap pelaksanaan NC. Hal ini tidak sesuai dengan pendapat Suharyati (2007) dan wawancara yang dilakukan dengan Kepala Bidang Bina Pelayanan Kesehatan, Penanggung Jawab Perkesmas di Dinas Kesehatan Kota Bandung dan para koordinator NC di Puskesmaspuskesmas yang aktif menjalankannya. Dukungan yang diberikan oleh Kepala Puskesmas, Dinas Kesehatan, dan Institusi Pendidikan Keperawatan sangat dirasakan manfaatnya oleh Puskesmas yang aktif menjalankan NC. Para informan tersebut juga mengakui bahwa peningkatan kerja sama dengan Institusi Pendidikan Keperawatan, merupakan upaya untuk mengatasi kendala terbatasnya jumlah tenaga kesehatan di Puskesmas.

\section{Simpulan}

Terdapat perbedaan faktor sumber daya manusia, pendanaan, material dan dukungan antara NC yang tidak aktif dan NC yang aktif. Penelitian juga menyimpulkan bahwa diantara faktor paling signifikan yang memengaruhi pelaksanaan NC adalah sumber daya manusia dan material.

\section{Saran}

Disarankan kepada Dinas Kesehatan Kota Bandung untuk meningkatkan kerjasama dengan Institusi Pendidikan Keperawatan yang akan menggunakan lahan praktek di Puskesmas-puskesmas wilayah kerja Dinas Kesehaatan Kota Bandung untuk mengadakan pembinaan kepada Puskesmas dan tenaga kesehatannya mengenai Perkesmas dan NC secara berkala dan berkesinambungan, serta menambah jumlah tenaga perawat di tiap Puskesmas. Dinas Kesehatan juga diharapkan dapat meminimalkan rotasi tenaga kesehatan, khususnya di Puskesmas-puskesmas untuk keberlangsungan program NC.

\section{Daftar Pustaka}

1. Departemen Kesehatan RI. (2006). Pedoman Penyelenggaraan Upaya Keperawatan Kesehatan Masyarakat di Puskesmas. Jakarta: Departemen Kesehatan.

2. Strass, Peggy., and Ellen Billay. (2008). A Public health Nursing Initative to Promote Antenatal Health. Diakses melalui http://web.ebscohost.com [11/10/2012]

3. Kneipp, Shawn M., John A. Kairalla, Barbara J. Lutz, Deidre Pereira, Allyson G. hall, Joan Flocks, JD, Linda Beeber, and Todd Schwartz. 2011. Public Health Nursing Case Management for Women Receiving Temporary Assistance for Needy Families: A Randomized Controlled Trial Using Community-Based Participatory Research.

Melalui http://search.proquest.com [25/02/2013]

4. Indra., Hari. (2006). Pelaksanaan Program Perkesmas Keluarga Miskin di Kabupaten Agam. Semarang: Universitas Diponegoro.

5. Daruji, M. (2001). Hubungan Faktor Individu Petugas Koordinator Perkesmas dengan Pelaksanaan Tugas dalam Pengelolaan Program di Puskesmas Kabupaten Sleman Tahun 2001. Tesis. Semarang: Universitas Diponegoro. 
Diakses melalui http://eprints.undip.ac.id [6/11/2013].

6. Departemen Kesehatan RI. (2005). Penerapan Kebijakan Upaya Keperawatan Kesehatan Masyarakat di Puskesmas. Jakarta: Direktorat Bina Pelaayanan Keperawatan Ditjen Bina Yanmed-Depkes RI.

7. Thabrany, Hasbullah. (2006). Pendanaan Kesehatan di Indonesia: Penyakit Kronis yang Berkomplikasi Kebodohan dan Kemiskinan. Diakses melalui http://staff.ui.ac.id [28/3/2013].

8. Suhadi. (2008). Masalah Pembiayaan Kesehatan di Indonesia. Diakses melalui http://cimsascoph.wordpress.com [13/11/ 2012].

9. Dinas Kesehatan Provinsi Jawa Barat. (2013). Evaluasi Perkesmas Tahun 2012. Bandung: Bina Yankes.

10. Septiono. (2007). Evaluasi Pelaksanaan Program Perkesmas dalam Meningkatkan Kinerja Puskesmas di Mantrijeron Kota Yogyakarta. Semarang: Universitas Diponegoro.

11. Kemenkes. (2001). Pedoman Supervisi/Pembinaan Upaya Kesehatan Puskesmas. Jakarta: Dirjen BinKesMas.

12. Nogi, H. (2007). Manajemen Publik. Jakarta: PT Grasindo.

13. Permana, Iwan. (2011). Faktor-Faktor yang Mempengaruhi Pelaksanaan Program Perawatan Kesehatan Masyarakat di Puskesmas Wilayah Kota Sukabumi. Tesis. Bandung: Universitas Padjadjaran.

14. Yuniar Syanti Rahayu, Dian. (2011). Pengaruh Faktor Internal dan Faktor Eksternal Perawat terhadap Kinerja Perawat dalam Melaksanakan Perkesmas di Puskesmas Kota Bandung. Tesis. Bandung: Universitas Padjadjaran.

15. Dinas Kesehatan Provinsi Jawa Barat. (2006). Pengelolaan Sentra Keperawatan Komunitas. Bandung: Tim Pengembangan Keperawatan Komunitas.
16. Suharyati. (2007). Nursing Center: Konsep dan Aplikasi. Bandung: Yayasan Nursentra.

17. Donabedian, Avendis. (1980). Exploration in Quality Assesment and Monitoring the Definition of Quality and Approaches to its Assesment. Michigan: Health Administration Press.

18. Sastroasmoro, S. \& Ismail, S. (2008). Dasar-Dasar Metodologi Penelitian Klinis (Edisi Ketiga). Jakarta: Sagung Seto.

19. Murti, Bhisma. (2011). Validitas dan Reliabilitas Pengukuran. Solo: Fakultas Kedokteran UNS. Diakses melalui http://fk.uns.ac.id [8/04/2013].

20. Nazir, Moh. (2011). Metode Penelitian. Bogor: Ghalia Indonesia.

21. Arikunto, Suharsini. (2006). Prosedur Penelitian Suatu Pendekatan Praktek. Jakarta: PT Rineka Cipta.

22. Dahlan, Muhaamad Sopiyudin. (2011). Statistik untuk Kedokteran dan Kesehatan. Jakarta: Salemba medika.

23. Dharma, Kelana Kusuma. (2011). Metodologi Penelitian Keperawatan: Panduan Melaksanakan dan Menerapkan Hasil Penelitian. Jakarta: Trans Info Media.

24. Septino, Tien. (2007). Hubungan Efektivitas Pelaksanaan Perawatan Kesehatan Masyarakat di Kabupaten Lima puluh Kota. Tesis. Yogyakarta: Universitas Gajah Mada. Diakses melalui http://lrckmpk.ugm.ac.id [6/11/2013].

25. F, Phillips, James., Ayaga A Bawah., Fred N Binka. (2006). Accelerating Reproduvtive and Child Health Programme Impact with CommunityBased Services: The Navrongo Experiment in Ghana. Bulletin of the World Health Organization 2006; 84: 949-955, diakses melalui http://web.ebscohost.com [15/7/ 2012]

26. As'ad, M. (2008). Psikologi Industri. Edisi 4 Cetakan Kesepuluh. Yogyakarta: Liberti.

27. Maqbul, Puja Laksana. (2007). Faktorfaktor yang Mempengaruhi Keaktifan 
Posyandu. Diakses melalui http://www.eprints.undip.ac.id [5/10/2013].

28. Sofia, Enizar. (2007). Hubungan Sumber daya Organisasi dengan Penerapan Sistem Informasi Manajemen Puskesmas di Kabupaten Langkat Tahun 2009. Tesis. Medan: Universitas Sumatera Utara. Diakses melalui http://repository.usu.ac.id [5/10/2013]

29. Rahmawati, Sri Pinti. (2007). Analisis Faktor Sumber Daya Manusia yang Berhubungan dengan Hasil Kegiatan Imunisasi Dasar Bayi oleh Petugas Imunisasi Puskesmas di Kabupaten Blora. Tesis. Semarang: Univversitas Diponegoro. Diakses melalui: http://eprints.undip.ac.id [6/11/2013].

30. Nurmalis. (2007). Evaluasi Pelaksanaan Perawatan Kesehatan Masyarakat oleh Bidan Desa di Kabupaten Agam. Tesis. Yogyakarta: Universitas Gajah Mada. Diaksses melalui http://arc.ugm.ac.id [5/11/2013]

31. Septiyani, Retno. (2012). Analisis Beberapa Faktor Individu, Organisasi, Psikologi yang Berhubungan dengan Kinerja Koordinator Program Keperawatan Kesehatan Masyarakat (PERKESMAS) di Puskesmas Kota Semarang Tahun 2012. Tesis. Semarang: Universitas Diponegoro. Diakses melalui: http://eprints.undip.ac.id [6/11/2013] 